\title{
Size at sex change in protogynous labroids, prey body size distributions, and apex predator densities at NW Hawaiian atolls
}

\author{
Edward E. DeMartini ${ }^{1, *}$, Alan M. Friedlander ${ }^{2}$, Stephani R. Holzwarth ${ }^{3}$ \\ ${ }^{1}$ NOAA Fisheries, Pacific Islands Fisheries Science Center, 2570 Dole Street, Honolulu, Hawaii 96822-2396, USA \\ ${ }^{2}$ NOAA, National Ocean Service, National Centers for Coastal Ocean Science - Biogeography Program, and \\ The Oceanic Institute, Makapuu Point/41-202 Kalanianaole Highway, Waimanalo, Hawaii 96795, USA \\ ${ }^{3}$ University of Hawaii, Joint Institute for Marine and Atmospheric Research, 1125B Ala Moana Boulevard, Honolulu, \\ Hawaii 96814, USA
}

\begin{abstract}
Body sizes at protogynous (sequential, female-to-male) sex change are described for 8 species of labroid fishes (4 labrids, 4 scarids) based on in situ diver observations of the sizes of sexrelated color morphs for populations at atolls in the NW Hawaiian Islands. Sizes at sex change are deduced from the median overlap in size distributions of initial phase (IP: female or female and precocious male) and terminal phase (TP) male individuals for each labroid species and from the median sizes of transitional morph individuals of the endemic, spectacled parrotfish Chlorurus perspicillatus. Relative (to maximum) sizes at sex change vary significantly among 4 major species and, within these species, among the 6 reef populations, a finding that contrasts with a recent model of invariant relative size at sex change in protogynous fishes. Overall median size at sex change is compared to the density of a large carangid (giant trevally Caranx ignobilis, the biomass-dominant apex predator) and to that of the respective labroid species population at each atoll. Size at sex change is inversely related to the density of giant trevally but not meaningfully related to the density of the respective labroid population. The size distributions of the labroids-like those of all other prey reef fishes - are strongly skewed toward smaller and larger fish at atolls with higher and lower densities, respectively, of giant trevally. Altogether these observations strongly suggest that higher mortality from predation at greater predator densities, rather than slower growth rates under greater intraspecific competition at higher prey densities, is the cause of the observed differences among atolls in prey attributes. We suggest that prey body size distribution can potentially provide a sensitive measure, complementary to predator density, for assessing changes in the abundance of apex predators on coral reefs. Phenotypic indices of size at sex change from adult female to male in sexually dimorphic labroids with striking differences in coloration (that facilitate underwater observations) have great potential as nondestructive alternatives to gonad examination requiring specimen sacrifice. Labroid color change thus represents a potentially useful index for assessing changes in the functional structure of coral reef fish assemblages and reef ecosystems.
\end{abstract}

KEY WORDS: Apex predation · Population density $\cdot$ Prey body size distribution · Protogynous sex change $\cdot$ Labroids $\cdot$ NW Hawaiian Islands

\section{INTRODUCTION}

Protogyny (sequential sex change from adult female to adult male) is a widespread trait among diverse lineages of coral reef fishes and is especially prevalent among the labroid fishes of the families Labridae (wrasses) and Scaridae (parrotfishes). Most species of labroids are protogynous and sexually dichromatic, with at least 2 color morphs - a usually drab-colored 'initial phase' (IP, either female or female and preco- 
cious male), and a brighter-colored 'terminal phase' (TP) male (Robertson \& Warner 1978, Warner \& Robertson 1978). In some lineages of protogynous fishes, 2 types of males occur: in some groups males are monandric (all derived from sex-changed females), whereas in other groups (like most scarinine parrotfishes of the genera Scarus and Chlorurus: Robertson et al. 1982), males are diandric, i.e. derived from either undifferentiated juveniles or from sex-changed females. With few exceptions, changes in coloration and sex are synchronous in scarids (Choat \& Robertson 1975, Bruce 1980); less is known about sex and color change synchronicity in labrids (Warner \& Robertson 1978, Moyer 1991). Phenotype has been successfully used as a proxy for internal gonad examination when estimating body size at maturational sex change in protogynous labrids (Platten et al. 2002) and scarids (Hawkins \& Roberts 2003).

Sex change in labroids is behaviorally mediated in response to frequency-dependent selection, usually if not invariably in accordance with the size-advantage hypothesis (Warner 1975, 1988, Warner et al. 1975). According to this hypothesis, individuals on average obtain disproportionately more matings as males when relatively large; hence selection favors individuals that change sex from female to male above a given body size. This size is often population specific and relative within a population because it is determined by local growth and mortality schedules that reflect environmental factors (population density, competition for mates of the opposite sex and other resources, and cropping by predators: Alonzo \& Mangel 2004). Local population density and predation mortality thus are important co-determinants of size at protogynous sex change. Mortality resulting from human extraction is also recognized as a key influence of size at sex change in sequential hermaphrodites (Armsworth 2001, Petersen \& Warner 2002).

The NW Hawaiian Islands (NWHI) are a remote, largely uninhabited group of small islands, atolls and submerged banks that extend over $2000 \mathrm{~km}$ northwest of the high, windward, and populated Main Hawaiian Islands (MHI). Large-bodied labroids rank among the most abundant coral reef fishes at shallow $(<18 \mathrm{~m})$ depths in the NWHI (Friedlander \& DeMartini 2002), particularly at the 3 most ancient ( 26 to 28 million yr old) emergent reefs - Pearl and Hermes (PHR), Kure (KUR), and Midway (MID), which are all true atolls with distinct forereef, backreef and lagoonal patch reef habitats) at the leeward extreme $\left(29\right.$ to $\left.30^{\circ} \mathrm{N}\right)$ of the archipelago (DeMartini \& Friedlander 2004). A number of these species (including several scarids formerly listed in the genus Scarus) - the endemic, spectacled parrotfish Chlorurus perspicillatus and the bullethead parrotfish C. sordidus, the Hawaiian hogfish Bodianus bilunulatus albotaeniatus (a labrid that is an endemic subspecies), and another endemic scarid, the regal parrotfish Scarus dubius-are particularly common and abundant. All these species exhibit extreme sexual dimorphisms in body size and coloration (Randall 1996), and all populations include large brightly colored TP fish that aggressively dominate within social groups of smaller IP fish (E. DeMartini unpubl. obs.). Prior observations of these and other labroids at French Frigate Shoals (FFS) and MID in the NWHI (DeMartini et al. 2002) suggested that body sizes at sex change can vary appreciably within species and among reef populations throughout the NWHI.

In this paper we estimate sizes at protogynous sex change for populations of selected, large-bodied labroids at the aforementioned 3 true atolls and (secondarily) at FFS, Maro Reef (MAR), and Lisianski Island/ Neva Shoals (LIS), three 12 to 23 million yr old, lowerlatitude $\left(24.5\right.$ to $\left.26.8^{\circ} \mathrm{N}\right)$ drowned atolls (DeMartini \& Friedlander 2004). Body size distributions are described for the 4 most common and abundant of these labroids (major species each comprising $>10 \%$ of the selected labroid aggregate), for all large-bodied and sexually dimorphic labroids pooled (8 species), and for the aggregate of all other prey reef fishes. We also evaluate the entire prey fish size spectrum and compare spectra among reefs. We further relate size at sex change and body size distributions to density of the respective reef population and compare size at sex change of the labroids and the body size distributions of labroids and other reef fish prey to abundance of giant trevally Caranx ignobilis, the biomass-dominant apex predator in the NWHI (Friedlander \& DeMartini 2002). The benefits of using nondestructive visual survey techniques to index size at sexual maturity in sexually dimorphic labroids are discussed. We further explore the use of related changes in body size distributions of prey species as a relatively precise proxy for predation intensity (apex predator abundance) that can be used to help monitor changes in reef ecosystem structure and function.

\section{MATERIALS AND METHODS}

Labroid size at sex change. Body sizes at sex change were described based on 2 independent methods, both requiring in situ visual estimates of body size. Interobserver variation in body length estimates on our surveys has been $15 \%$ or less (DeMartini 2004). Body size of sex-transforming ('transitional': Choat \& Robertson 1975) individuals was estimated by E. E. DeMartini for all adult-morph individuals of spectacled parrotfish encountered during routine underwater visual surveys (Friedlander \& DeMartini 2002) conducted during 
September to October 2000 and 2002. Transitionals were recognized by a color pattern that was a mixture of the 2 adult morphs (i.e. maroon body color with a faint to moderately expressed 'eyeglass' pattern on the snout). Body sizes at sex change were further characterized for major labroid species based on median overlaps in size distributions of IP and TP fish tallied by E. E. DeMartini, A. M. Friedlander, and several other trained individuals. All labroids were tallied by species, but analyses of IP and TP length distributions were restricted to 8 selected species (4 labrids, 4 scarids) of conspicuous, sexually dichromatic and large-bodied (adults $>20 \mathrm{~cm}$ total length, TL) species whose TP fish were unequivocably recognizable and consistently scored by all observers (see Table 1). Strikingly dichromatic but small-bodied species like the belted wrasse Stethojulis balteata, and abundant, large-bodied but weakly dichromatic species like the blacktail wrasse Thalassoma ballieui, were excluded. Species that were rare at the far NW atolls (e.g. the palenose parrotfish Scarus psittacus) were also not considered. Median overlaps in frequency distributions were calculated for IP and TP fish of each of the major species, and for the aggregate of all selected labroid species at each reef.

Prey size distributions. Additional size tallies were used to describe length distributions for the aggregate of all (including labroid) prey fishes. Prey fishes comprised all taxa except the 18 species of apex predators listed by DeMartini \& Friedlander (2004). Lengths of all fish $\geq 10 \mathrm{~cm}$ TL were estimated to the nearest $5 \mathrm{~cm}$ (Friedlander \& DeMartini 2002). We restricted our analyses to individuals of $\geq 10 \mathrm{~cm}$ TL because individuals smaller than this represent $<5 \%$ of the prey consumed by large ( $\geq 50 \mathrm{~cm}$ TL) carangid predators on NWHI reefs (J. D. Parrish unpubl. data). Restricting estimates to fish $\geq 10 \mathrm{~cm}$ TL largely eliminated the influence of recent recruitment on size distributions. Recruitment was high at all 3 true atolls evaluated herein, especially MID and KUR, during 2000 and 2002; spatial patterns of young-of-year and other small-bodied fishes $<10 \mathrm{~cm}$ TL at each of the 10 emergent NWHI reefs have been explored in detail by DeMartini \& Friedlander (2004). We focused our analyses on data collected at the aforementioned 3 true atolls because their physiographic similarities and the relatively short distances separating them (mean $150 \mathrm{~km}$, range 85 to $210 \mathrm{~km}$ : DeMartini \& Friedlander 2004) minimize the possibility that varying environmental influences such as habitat structure and latitudinal changes in water temperature might elicit differences in growth rates that could confound comparisons of body size distributions and sizes at sex change. We acknowledge these caveats when describing labroid sex change, prey body size, and predator density patterns at the 3 lower-latitude drowned atolls.
Fish densities. Numerical and biomass (kg or metric tons) densities per sampling unit and hectare (ha), depending on taxon, were estimated for each of the major labroids, the aggregate of all selected labroid species, all other prey reef fish taxa, and giant trevally, using 1 or more of several survey techniques. Multiple stations (number proportional to habitat area) were surveyed at each atoll. At each randomly located station, 2 divers conducted belt transects $\left(\mathrm{BT}_{\text {; }}\right.$ three $25 \mathrm{~m}$ long transects totaling $600 \mathrm{~m}^{2}$ area) and a third diver conducted modified stationary point counts (SPC; four $5 \mathrm{~min}$, timed surveys within near-bottom circular $(10 \mathrm{~m}$ radius) plots of $1257 \mathrm{~m}^{2}$ total area; see Bohnsack \& Bannerot 1986, Bortone \& Kimmel 1991). Fish on BT were tallied by $5 \mathrm{~cm}$ length classes for 'large' (>20 cm TL) and for 'small' (10 to $20 \mathrm{~cm}$ TL) individuals encountered on an initial 'swim-out' leg (while laying the transect line) and a return swim back along the laid line, respectively (Friedlander \& DeMartini 2002). On SPC, all species of relatively low density, moderate- to largebodied fishes $>25 \mathrm{~cm} \mathrm{TL}$, present within $5 \mathrm{~m}$ of the bottom in the plots were tallied by $5 \mathrm{~cm}$ TL class. Totals of 55, 47, and 27 stations were surveyed using BT and SPC at PHR, KUR, and MID, respectively. Another 30, 29 , and 59 respective stations were surveyed at LIS, MAR and FFS.

S. R. Holzwarth or 1 other trained observer conducted 'towed diver surveys' (TDS) while being pulled on a planing board by motorized small craft elsewhere at the same atoll on the same day. On TDS, all apex predators $>50 \mathrm{~cm}$ TL encountered within an approximately 5 to $10 \mathrm{~m}$ wide swath while board and diver were towed at an average speed of 1.7 knots (mean $2.66 \mathrm{~km}$ tow length, mean 50 min duration dive = station) were noted by $25 \mathrm{~cm}$ TL class on a plastic form, analogous to those used for tallying fishes on BT and SPC, bearing preprinted species names. Only stations with $>10 \mathrm{~m}$ lateral visibility were used in analyses. TDS were conducted at 46, 27, and 15 stations at PHR, KUR, and MID, respectively.

The densities of labroids and other prey fish taxa were most appropriately characterized using BT. Both SPC and BT were needed to generate sufficient numbers for the labroid size frequency distributions. Apex predator densities were estimated using both SPC and TDS (each method, with its own biases, providing an independent estimate), and these were evaluated separately and combined. Biomass densities were emphasized for apex predators so as to be consistent with the study of DeMartini \& Friedlander (2004). Comparative estimates for selected labroids, other prey taxa, and giant trevally were restricted to forereef and backreef habitats because large-bodied labroids and trevallies were conspicuously less abundant (and more variable) on lagoonal patch reefs, the third major habitat sur- 
veyed at atolls (Friedlander \& DeMartini 2002, DeMartini \& Friedlander 2004). For each of the 2 habitats evaluated, habitat complexities were similar at the 3 true atolls and thus did not confound comparisons of fish densities among these atolls. All habitats were included when evaluating the drowned atolls, where habitat types were not clearly delimited. Restricting our estimates to fish of $>10 \mathrm{~cm}$ TL also largely eliminated the short-term effects of recruitment on prey density estimates (as well as the effects that smallbodied reef-resident piscivores might exert on prey). Using survey data collected during 2 yr over a 3 yr period further dampened the influence of year-class fluctuations on the replenishment of prey populations. Friedlander \& DeMartini (2002) and DeMartini \& Friedlander (2004) have further specified the habitats and survey protocols.

Statistical analyses. Median body lengths and length distributions were compared among reefs by $k$-sample median and Kolmogorov-Smirnov (K-S) tests (Siegel \& Castellan 1988; proc NPAR1WAY: SAS 1999). Comparisons of fish densities and evaluations of size-density relations used either nonparametric or parametric statistics (e.g. Spearman rank correlation, $\mathrm{r}_{\mathrm{S}}$ : Siegel \& Castellan 1988; least squares regression and ANOVA: Zar 1984; proc REG, proc GLM: SAS 1999), depending on sampling distributions of the data. Body sizes at which $50 \%$ of all individuals $\geq 10 \mathrm{~cm}$ TL transformed from IP to TP were estimated for each of the major labroid species at each atoll by fitting a logistic model: $P=100 /\left(1+\exp ^{(a-b \mathrm{TL})}\right)$, where $P=$ percentage TP at $x \mathrm{~cm} \mathrm{TL}$; and $L_{50}=(-a / b)$. This model was fit using nonlinear regression and maximum likelihood (proc NLIN: SAS 1999). Prey fish size spectra were described for each atoll using least squares regression to relate $\log 10$-transformed numerical and biomass densities to body length. Lengths were first standardized to the midpoint of the size distribution at the respective reef in order to remove the correlation between slope and intercept (Dulvy et al. 2004b, Graham et al. 2005). Size spectra were compared among reefs using least squares ANCOVA (proc GLM: SAS 1999). The criterion for significance of all tests was $p=0.05$, adjusted where necessary for multiple comparisons by the Bonferroni correction $(p=0.05 / m)$, where $m$ is the number of comparisons within the series (Manly 1991).

\section{RESULTS}

\section{Size at sex change and size distributions of labroids}

Median body sizes at sex change were well described by logistic curve fits to percentage terminal phase by length class ( $\mathrm{r}^{2}$ range 0.58 to 0.99 , all $\mathrm{p} \leq 0.05$ ) at each of the 3 true atolls. Body sizes at transformation were generally smaller at PHR for all major labroids except Hawaiian hogfish (Table 1, Fig. 1). The overall median body sizes of each major species except Hawaiian hogfish also differed among atolls (median tests, $\mathrm{p}<0.0001$; Table 2). Body size at sex change of spectacled parrotfish, based on visual tallies of transitional individuals, was larger at MID than at KUR and PHR ( $k$-sample median test, $\chi^{2}=14.3$, df $=2, p<$ 0.0001; Table 2). Both overall body size distributions and those of TP individuals of all selected labroid species pooled were skewed toward smaller body sizes at PHR (K-S tests, all p < 0.001; Fig. 2). The 4 major labroid species together contributed $>85 \%$ to total counts of the 8 selected labroids (Table 1).

\section{Body sizes of prey fishes}

Median body sizes of all other reef fish prey pooled likewise were smaller at PHR ( $k$-sample median test,

Table 1. Data for 8 select species of large-bodied, conspicuously dimorphic labroids evaluated for among-atoll differences in median body size and size at protogynous sex change, showing percent contribution to total tallies of select labroids, and also estimated body size (total length) at sex change for each of the 4 major species, based on diver observations at Kure (KUR), Midway (MID), and Pearl and Hermes (PHR) atolls during September to October 2000 and 2002. Boldface indicates that taxon is endemic to Hawaiian Islands at species (or subspecies for Bodianus bilunulatus) level

\begin{tabular}{|c|c|c|c|c|c|}
\hline Species & & Hawaiian name & Common name & $\%$ contribution & $\begin{array}{l}\text { Size }(\mathrm{cm}) \text { at sex change } \\
\text { (PHR, KUR, MID) }\end{array}$ \\
\hline \multirow{4}{*}{ Labridae } & Anampses cuvier & ‘opule & Pearl wrasse & 3.2 & \multirow{4}{*}{$38.6,40.5,39.6$} \\
\hline & Bodianus bilunulatus $^{\text {a }}$ & 'a'awa & Hawaiian hogfish & 17.2 & \\
\hline & Coris flavovittata & hilu & Yellowstriped coris & 6.5 & \\
\hline & Thalassoma purpureum & hou & Surge wrasse & 3.2 & \\
\hline \multirow[t]{4}{*}{ Scaridae } & Calotomus zonarchus & ponuhunuhu & Yellowbar parrotfish & 2.1 & \\
\hline & Chlorurus perspicillatus & uhu uliuli & Spectacled parrotfish & 38.3 & $44.1,49.8,47.8$ \\
\hline & Chlorurus sordidus & uhu & Bullethead parrotfish & 15.3 & $35.1,38.9,47.2$ \\
\hline & Scarius dubius & lauia & Regal parrotfish & 14.2 & $26.4,39.8,35.1$ \\
\hline
\end{tabular}



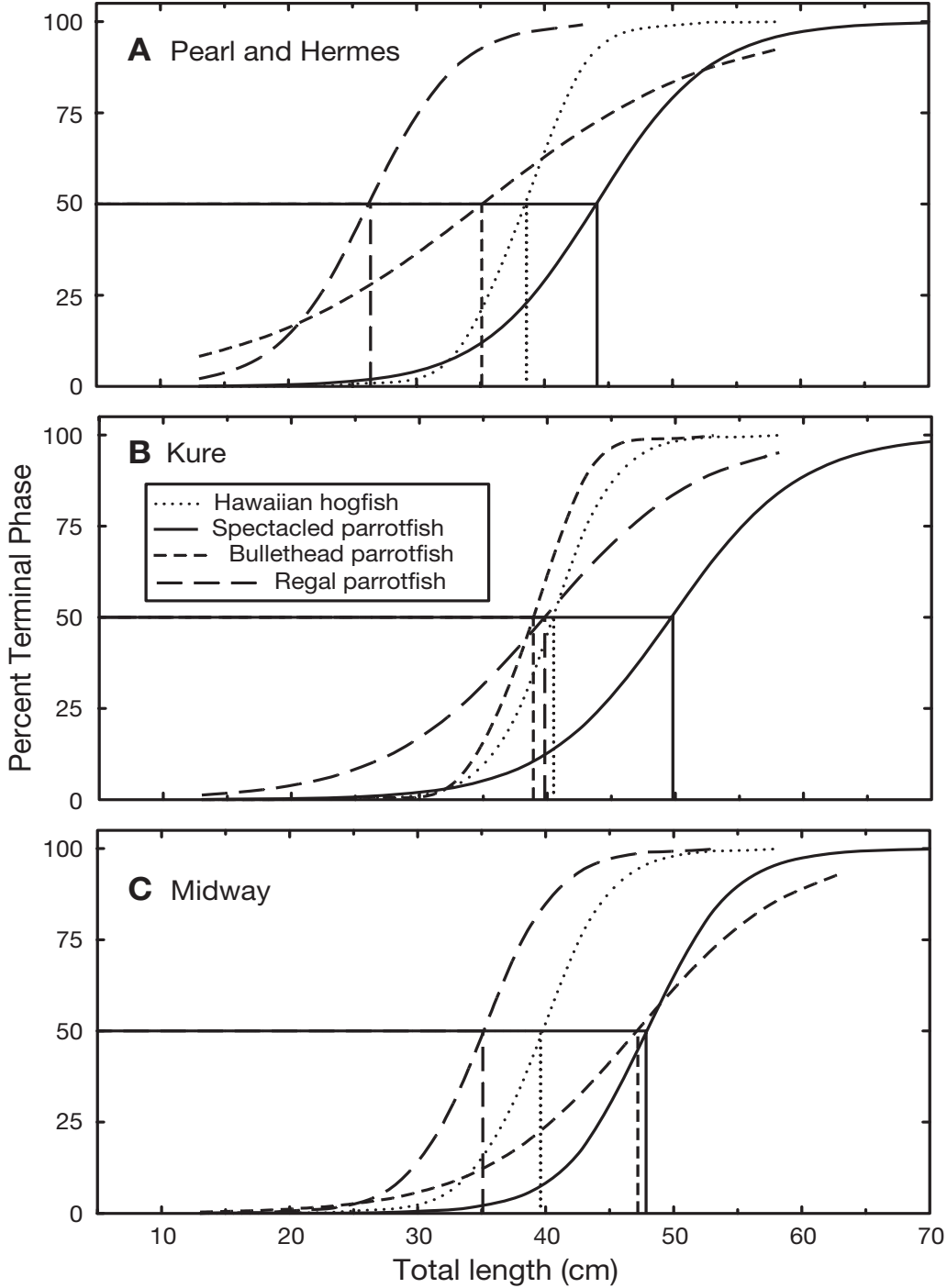

Fig. 1. Scatterplots and logistic spline curves (predicted fits) of percentage terminal phase (for all individuals observed, both initial and terminal phases) by $5 \mathrm{~cm}$ total length class, for each of 4 major species of labroids (1 labrid plus 3 scarids), at Pearl and Hermes, Kure, and Midway atolls in the NW Hawaiian Islands during September to October 2000 and 2002. Vertical lines indicate estimated body length at which $50 \%$ of individuals are terminal phase. Specific names in Table 1 $\mathrm{p}<0.001$; Table 2). Body size distributions were generally skewed toward smaller values at PHR compared to either KUR or MID (K-S tests, all $\mathrm{p}<0.001$; Fig. 3). Size spectra calculated for densities of labroid and all other prey taxa pooled (total $\approx 150$ species) further supported the general pattern of relatively more fish of smaller body sizes at PHR and disproportionate abundances of large prey individuals at MID. Densities in all cases declined logarithmically at larger body sizes (numbers: $\mathrm{r}^{2}=0.94$ to 0.97 ; biomass: $r^{2}=0.71$ to 0.91 ; all $p<0.0001$; Fig. 4). The intercept of the biomass-to-body size relation (i.e. abundance at the midpoint of the length distribution) was significantly higher at MID vs. either of the other 2 atolls $(p=0.014$; Table 3$)$. An analogous pattern for numerical density was suggestive $(p=$ 0.145 ; Table 4 ). The slope (rate of decline) in density with increased body size appeared greatest at PHR for both numbers and biomass but was not significant (Tables $3 \& 4$, Fig. 4).

\section{Labroid and other prey fish densities}

The densities of Hawaiian hogfish were indistinguishable (Table 5, Fig. 5A), but those of each of the 3 major parrotfish species differed among atolls. Both IP and TP spectacled parrotfish were denser at MID (2-way ANOVA on log-transformed data: Table 5, Fig. 5B). Densities of bullethead and regal parrotfishes were higher at PHR than at the other 2 atolls, but only for IP fish (Table 5, Fig. 5C,D). The biomass density of all prey reef fishes, particularly those above median body length, was greater at MID (Table 5, Fig. 5E).
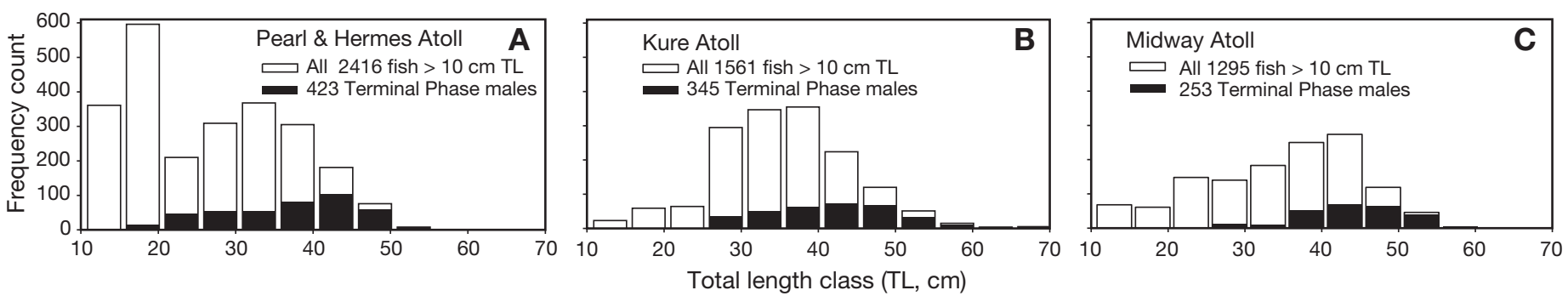

Fig. 2. Body size (total length, TL) frequency distributions of aggregate of 8 species (combined data) of select (large-bodied, conspicuously dichromatic) labroids $\geq 10 \mathrm{~cm}$ TL, comprising 4 labrids and 4 scarids (listed in Table 1), observed by divers on belt transects and stationary point count surveys at Pearl and Hermes, Kure and Midway atolls in the NW Hawaiian Islands during September to October 2000 and 2002 . Tallies are partitioned by initial and terminal phase individuals 
Table 2. (A) Total body lengths (TL, cm) of transforming spectacled parrotfish and (B) measures of central tendency for TL distributions of spectacled parrotfish, Hawaiian hogfish, bullethead parrotfish, regal parrotfish, and all other prey reef fishes observed by divers at Pearl and Hermes (PHR), Kure (KUR) and Midway (MID) atolls during September to October 2000 and 2002. ${ }^{*}$ Significant at $\mathrm{p}<0.0001$ based on $k$-sample median tests with Bonferroni corrections. Specific names in Table 1

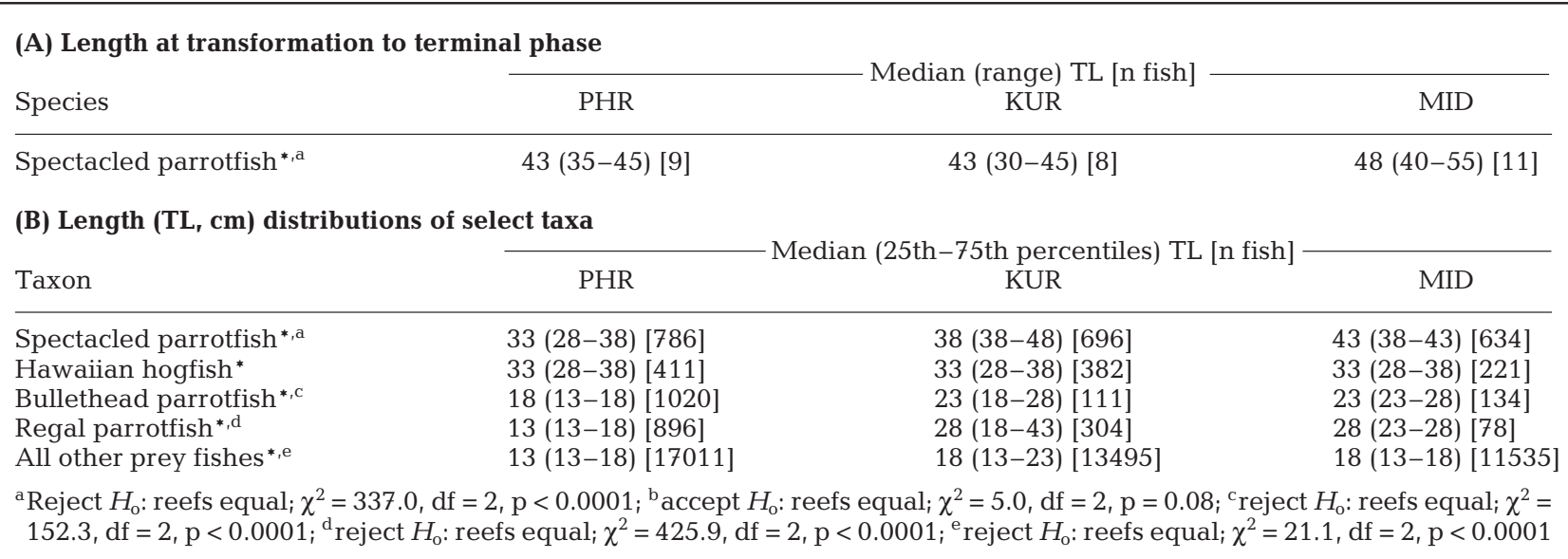

\section{Apex predator densities and relations}

Giant trevally were denser at PHR than at the other 2 atolls, based on SPCs, and the same pattern was suggested by TDS data (Table 6, Fig. 6). A combined probability for giant trevally was significant for both survey methods $(-2 \ln \Sigma \mathrm{p}=25.5,4 \mathrm{df}, \mathrm{p}<0.001$; Sokal \& Rohlf 1981). Both methods of characterizing giant trevally densities were imprecise: coefficients of variation (100 [standard deviation/mean]) ranged from nearly $200 \%$ to over $500 \%$ among reefs. Comparisons using the 2 methods nonetheless supported each other. Giant trevally comprised about 66 and $89 \%$ of all apex predator biomass at PHR based on TDS and SPC, respectively. Analogous percentages at MID were much lower (10 and $12 \%$ ). Percentages for giant trevally at KUR were intermediate (61 and $36 \%$ ). Biomass and numerical density patterns were similar for giant trevally (biomass densities only shown). Size frequency distributions were dominated by 60 to $100 \mathrm{~cm}$ fish at each of the 3 atolls, although a secondary mode of very large (125 to $150 \mathrm{~cm}$ ) adult fish was observed only at PHR.
Patterns in giant trevally densities were related to characteristics of the respective prey population as predicted at the 3 true atolls. In general, the rankings of median giant trevally biomass were inversely correlated with rankings of median body size at sex change in major labroids, median body size of all selected labroids, and the median body sizes of all other prey fishes, but the numbers of matched comparisons (reefs) were too few for meaningful statistical analysis if limited to just these 3 reefs.

\section{Prey attributes and predator densities including drowned atolls}

Analogous analyses of patterns at the 3 lower-latitude, drowned atolls, provided for qualified, secondary comparison, indicate that the abovementioned relations among size at sex change of the 4 major species of labroids, the median body sizes of all 8 selected labroids and other prey fishes, and predator abundance are more spatially general than just for the 3
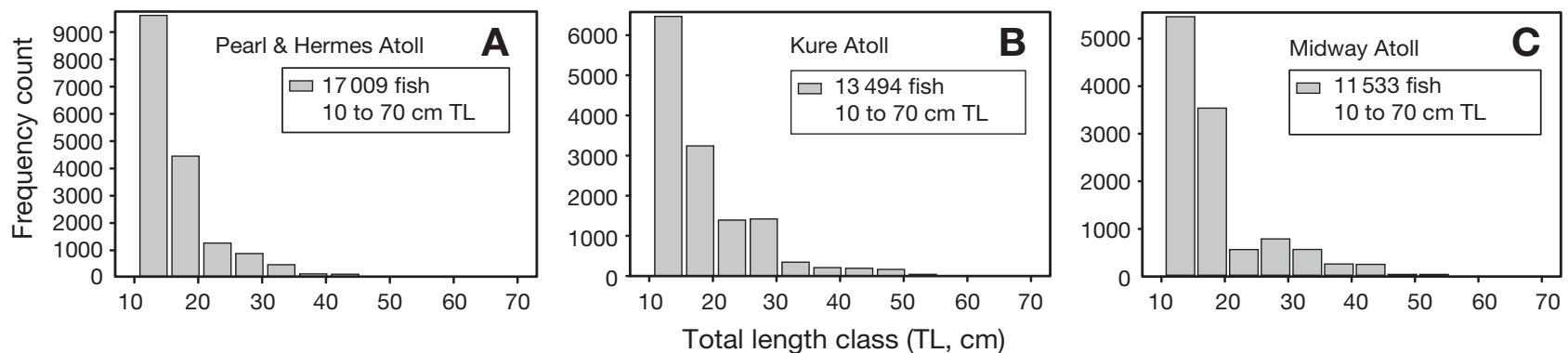

Fig. 3. Body size (total length, TL) frequency distributions of aggregate of all other taxa (i.e. not shown in Fig. 2) of prey reef fishes $\geq 10 \mathrm{~cm}$ total length observed by divers on belt transects at (A) Pearl and Hermes, (B) Kure, and (C) Midway atolls in the NW Hawaiian Islands during September to October 2000 and 2002. Note variable scale on $y$-axes 
Table 3. (A) Summary statistics for size spectra characterized as relationship between fish abundance, indexed by biomass density $\left(\mathrm{kg} \mathrm{ha}^{-1}\right.$ ), and body size for aggregate of select labroid and all other prey reef fish taxa $\geq 10 \mathrm{~cm}$ in total length observed by divers at Pearl and Hermes (PHR), Kur (KUR) and Mid (MID) atolls during September to October 2000 and 2002. (B) Results of ANCOVA tests comparing size spectra (densities vs. body size) among the 3 atolls. All analyses used square-root $\mathrm{N}$ weightings

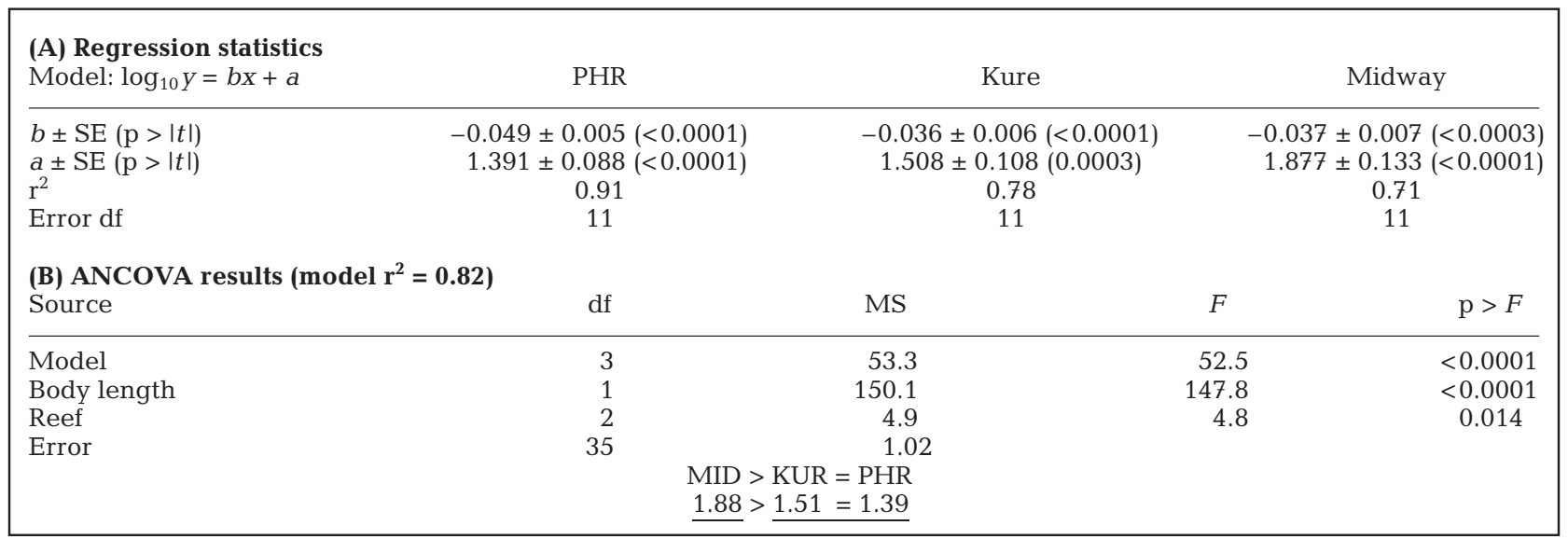

Table 4. (A) Summary statistics for size spectra characterized as relationship between fish abundance, indexed by numerical density $\left(\mathrm{N} \mathrm{ha}^{-1}\right)$, and body size for aggregate of select labroid and all other prey reef fish taxa $\geq 10 \mathrm{~cm}$ in total length observed by divers at Pearl and Hermes (PHR), Kur (KUR) and Midway (MID) atolls during September to October 2000 and 2002. (B) Results of ANCOVA tests comparing size spectra (densities vs. body size) among the 3 atolls. All analyses used square-root N weightings

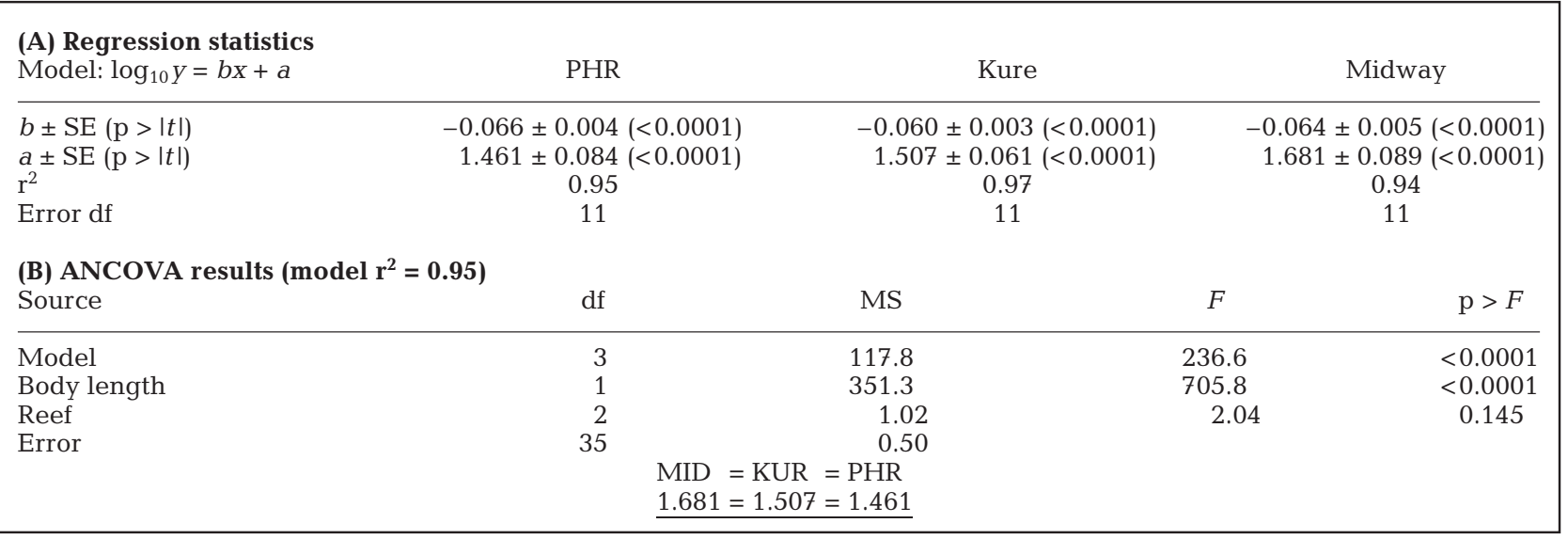

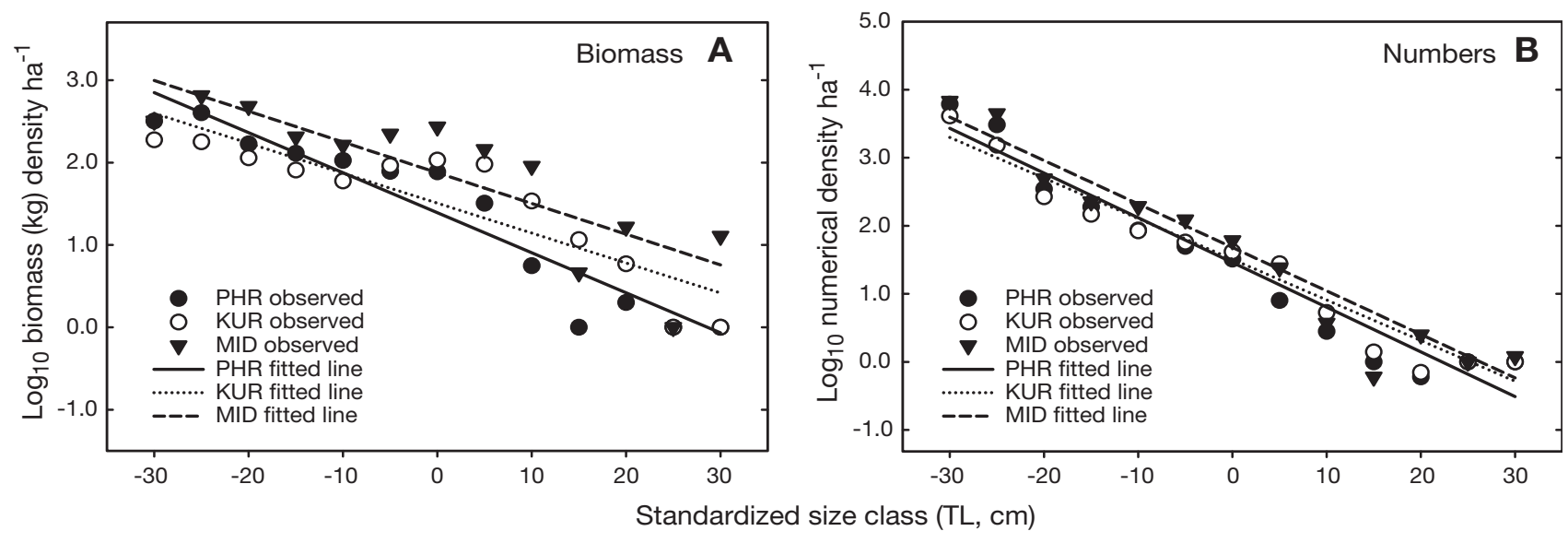

Fig. 4. (A) Biomass and (B) numerical density size spectra for aggregate of all selected labroids and all other prey reef fish taxa $\geq 10 \mathrm{~cm}$ total length observed by divers on belt transects at Pearl and Hermes (PHR), Kure (KUR), and Midway (MID) atolls in the NW Hawaiian Islands, during September to October 2000 and 2002 
Table 5. Summary results of ANOVAs comparing density among reefs for numbers of spectacled, bullethead and regal parrotfishes, and Hawaiian hogfish; and biomass of all prey fishes observed by divers at Pearl and Hermes, Kure, and Midway atolls during September to October 2000 and 2002. For A to D, densities are compared among atolls for fish less than (vs. greater than or equal to) population-specific median body size at sex change using $\log _{10}(x+1)$ density $\mathrm{ha}^{-1}$ and parametric 2 -way ANOVA. For $\mathrm{E}, \log _{10}(x+1)$ biomass $(\mathrm{kg}) \mathrm{ha}^{-1}$ are similarly compared among atolls for prey fish size groups below and above median body length at the respective atoll. For A to $\mathrm{E}, \mathrm{m}=4 ; \mathrm{p}_{\text {crit }}=0.05 / 4=0.0125 ; \mathrm{ns}: \mathrm{p}>0.01 ;{ }^{*} \mathrm{p} \leq 0.01{ }^{* *} \mathrm{p}<0.001 ;{ }^{* * *} \mathrm{p}<$ 0.0001 ; -: term ns (not significant), so deleted from model. Specific names in Table 1

\begin{tabular}{|c|c|c|c|c|c|}
\hline \multirow[t]{2}{*}{ Species } & \multirow[b]{2}{*}{$\begin{array}{l}\text { Model } \\
\mathrm{r}^{2}\end{array}$} & \multirow[b]{2}{*}{$\begin{array}{l}\text { Model df, } \\
\text { error df }\end{array}$} & \multicolumn{2}{|c|}{$F($ nominal $\mathrm{p}>F)$} & \multirow[b]{2}{*}{ Interaction } \\
\hline & & & $\begin{array}{l}\text { Phase or } \\
\text { size group }\end{array}$ & Reef & \\
\hline $\begin{array}{l}\text { (A) Spectacled } \\
\text { parrotfish }\end{array}$ & 0.47 & 3,252 & $\begin{array}{l}204.0^{* * *} \\
(<0.0001)\end{array}$ & $\begin{array}{l}7.74^{* *} \\
(0.0005)\end{array}$ & - \\
\hline $\begin{array}{l}\text { (B) Bullethead } \\
\text { parrotfish }\end{array}$ & 0.51 & 5,250 & $\begin{array}{c}97.8^{* * *} \\
(<0.0001)\end{array}$ & $\begin{array}{c}34.5^{* * *} \\
(<0.0001)\end{array}$ & $\begin{array}{c}29.7^{* * *} \\
(<0.0001)\end{array}$ \\
\hline $\begin{array}{l}\text { (C) Regal } \\
\text { parrotfish }\end{array}$ & 0.39 & 5,250 & $\begin{array}{c}79.0^{* * *} \\
(<0.0001)\end{array}$ & $\begin{array}{l}4.71^{*} \\
(0.01)\end{array}$ & $\begin{array}{l}5.16^{*} \\
(0.006)\end{array}$ \\
\hline $\begin{array}{l}\text { (D) Hawaiian } \\
\text { hogfish }\end{array}$ & 0.43 & 3,252 & $\begin{array}{l}188.0^{* * *} \\
(<0.0001)\end{array}$ & $\begin{array}{c}0.63 \\
(0.53)\end{array}$ & - \\
\hline $\begin{array}{l}\text { (E) All prey } \\
\text { fishes }\end{array}$ & 0.43 & 5,250 & $\begin{array}{l}108.8^{* * *} \\
(<0.0001)\end{array}$ & $\begin{array}{c}22.3^{* * *} \\
(<0.0001)\end{array}$ & $\begin{array}{c}8.33^{* *} \\
(0.0003)\end{array}$ \\
\hline
\end{tabular}

change and prey sizes at MAR and FFS (where trevally densities were intermediate to those at PHR and at KUR and MID) were similarly intermediate to the respective distribution at PHR vs. either KUR or MID (Fig. 7).

\section{DISCUSSION}

\section{Size at sex change}

Our data illustrate that the relative size at sex change (i.e. standardized to average maximum size in the particular speciespopulation) varies among species and among reef populations within species of labroids in the NWHI $\left(\chi^{2}\right.$ comparing multiple proportions: all $\mathrm{p}<0.001$; Zar 1984; Fig. 8). These observations are inconsistent with the model of Allsop \& West $(2003 a, b)$, which predicts an invariant relative size at sex change among (and, by implication) within species. Clearly, further model development is needed that extends predictions to encompass withintrue atolls. Labroid size at sex change, the median body sizes of all labroid and other prey fishes (each ranked from smallest to largest) and giant trevally density (ranked from lowest to highest) were inversely related among all 6 reefs (Kendall's coefficient of concordance $W=0.73$; $<0.01$; Siegel \& Castellan 1988; Fig. 7). Size at sex change and the overall sizes of prey fishes at LIS (where giant trevally were nearly as dense as at PHR) were relatively small, as at PHR. Size at sex
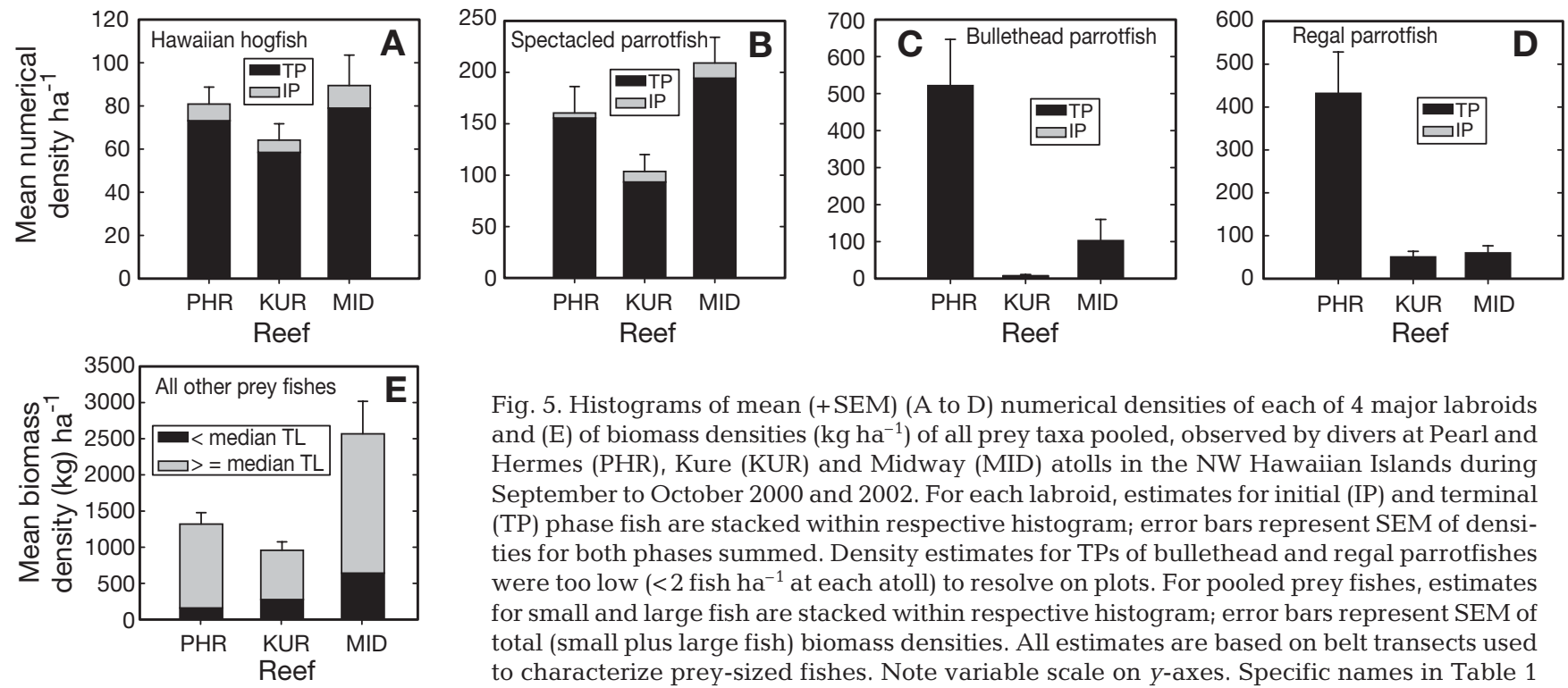

Fig. 5. Histograms of mean (+SEM) (A to D) numerical densities of each of 4 major labroids and (E) of biomass densities $\left(\mathrm{kg} \mathrm{ha}^{-1}\right)$ of all prey taxa pooled, observed by divers at Pearl and Hermes (PHR), Kure (KUR) and Midway (MID) atolls in the NW Hawaiian Islands during September to October 2000 and 2002. For each labroid, estimates for initial (IP) and terminal (TP) phase fish are stacked within respective histogram; error bars represent SEM of densities for both phases summed. Density estimates for TPs of bullethead and regal parrotfishes were too low ( $<2$ fish ha ${ }^{-1}$ at each atoll) to resolve on plots. For pooled prey fishes, estimates for small and large fish are stacked within respective histogram; error bars represent SEM of total (small plus large fish) biomass densities. All estimates are based on belt transects used to characterize prey-sized fishes. Note variable scale on $y$-axes. Specific names in Table 1 
Table 6. Caranx ignobilis. Results of Kruskal-Wallis 1-way ANOVAs comparing median biomass estimates of giant trevally during stationary point counts (SPC) and towed diver surveys (TDS) by divers at Pearl and Hermes (PHR), Kure (KUR), and Midway (MID) atolls during September to October 2000 and 2002. Separate analyses are presented for the 2 methods because SPC provided density estimates $\left(\mathrm{kg} \mathrm{ha}^{-1}\right)$ whereas TDS provided tallies $\left(\mathrm{kg} \mathrm{tow}^{-1}\right), \mathrm{df}=2$ in both cases, ${ }^{*} \mathrm{p}<0.0001$

\begin{tabular}{|llcc}
\hline $\begin{array}{l}\text { Survey } \\
\text { method }\end{array}$ & $\begin{array}{c}\text { Among-reef } \\
\text { pattern }\end{array}$ & $\begin{array}{c}\chi^{2} \text { test } \\
\text { statistic }\end{array}$ & $\mathrm{p}>\chi^{2}$ \\
\hline SPC & PHR $>$ KUR $=$ MID & 27.9 & $<0.0001^{*}$ \\
TDS & PHR $=$ KUR $=$ MID $^{\text {a }}$ & 5.3 & 0.07
\end{tabular}

${ }^{\mathrm{a}}$ Ranking of reefs is based on nominal estimates if not significantly different

phenomena currently fueling debate on the use of lifehistory invariants and reaction norms (Charnov 1993, Charnov \& Skulladottir 2000) for resolving phenotypic vs. genotypic responses of fishes to size-selective natural mortality and environmental perturbations including fishing (Reznick et al. 1990, Rijnsdorp 1993, Alonzo \& Mangel 2004, Barot et al. 2004, Olsen et al. 2004).

The among-atoll differences in size at sex change we observed probably represent neither genetic nor geographic differences in physical environments. Both the presence of habitats unsuitable for benthic-stage reef fishes (deep soft-sediment basins) and the distances

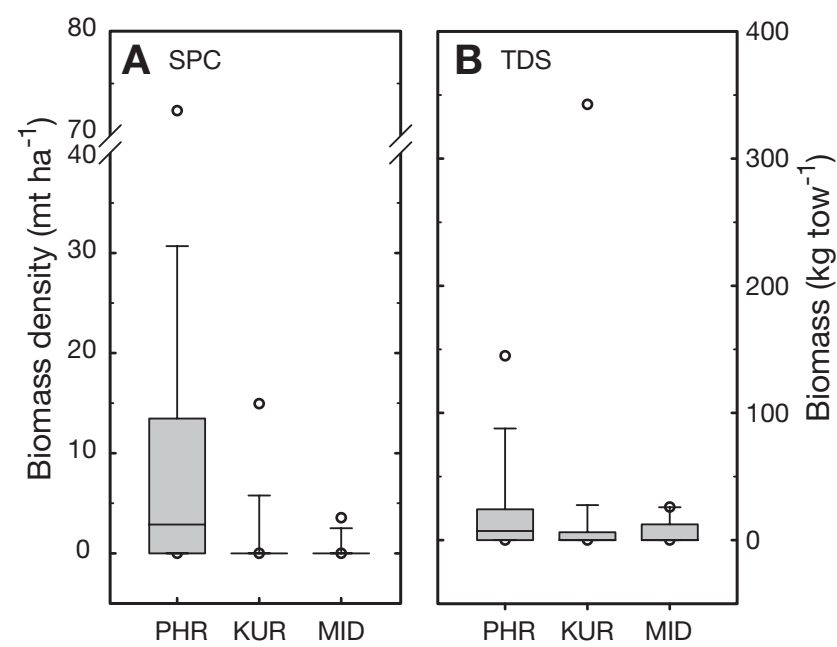

Fig. 6. Caranx ignobilis. Histograms of median (horizontal line), quartiles (box), 10th and 90th percentiles (whiskers), and 5th and 95th percentiles (o) of biomass of giant trevally observed by divers at Pearl and Hermes (PHR), Kure (KUR) and Midway (MID) atolls in the NW Hawaiian Islands during September to October 2000 and 2002 based on stationary point counts (SPC) and towed diver surveys (TDS). Separate estimates are presented because carangid abundances were characterized as biomass densities (mt ha ${ }^{-1}$ ) on SPC and biomass tallies $\left(\mathrm{kg} \mathrm{tow}^{-1}\right)$ on TDS

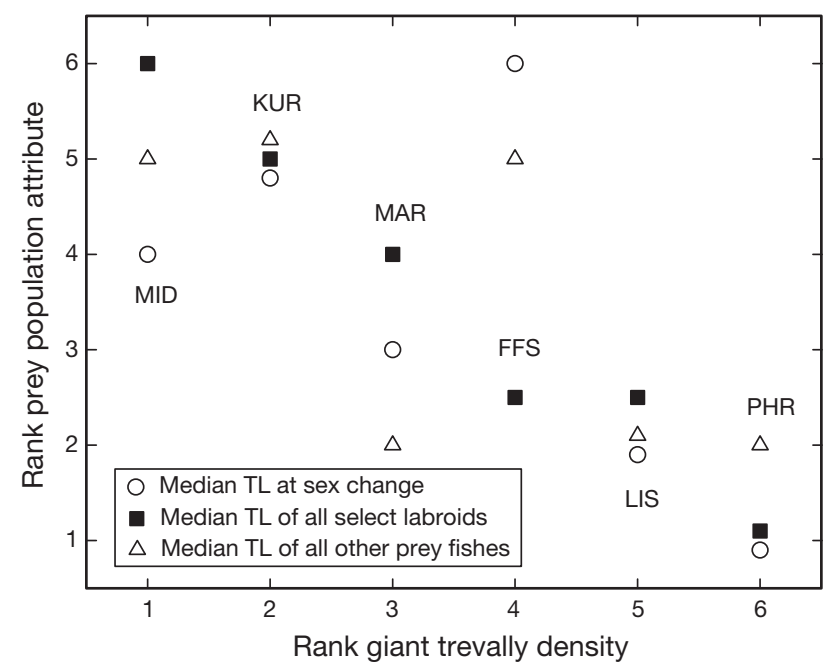

Fig. 7. Scatterplot of ranks of prey population attributes (median total length at sex change in the 4 major labroid species, median total lengths of all 8 selected species of labroids, and median total lengths of all other prey fishes) vs. ranks of giant trevally Caranx ignobilis densities, at each of the 3 true atolls (Pearl and Hermes, PHR; Kure, KUR; Midway, MID) and the 3 drowned atolls (Lisianski Island/Neva Shoals, LIS; Maro Reef, MAR; French Frigate Shoals, FFS) surveyed during September to October 2000 and 2002. For simplicity, densities of giant trevally are given for all reefs using only SPC counts. Labroids specified in Table 1

separating the 3 atolls (DeMartini \& Friedlander 2004) argue for the existence of discrete local populations of resident-stage reef fishes. However, even though the 3 true atolls are within less than 2 latitude degrees of one another and oceanographically similar (hence unlikely to differ meaningfully in water temperatures and related growth rates), the distances separating them are probably insufficient to prevent genetic exchange among the reef populations, given the 1 to 2 mo planktonic larval durations of most reef fish species. All Hawaiian labroids are broadcast spawners with pelagic eggs and larvae, and these and other populations of most reef fishes at the 3 atolls surely exchange some propagules each generation. Thus it is unlikely that the differences in body size at sex change that we observed among atolls reflect genetic divergence, even if some reef-specific reseeding might be occurring (DeMartini \& Friedlander 2004). Geertjes et al. (2004) described an analogous example for a scarid species in the Caribbean. That both median body size and size at sex change of each of 3 species of parrotfishes were consistently smallest at PHR, bolstered for spectacled parrotfish by evidence for the largest transitional individuals at MID, argues against a simple species-specific reason for the differences in life histories. The further observation that the median body size of all other prey-sized reef fishes (comprising benthic invertebrate feeders, secondary carnivores, and non-apex 


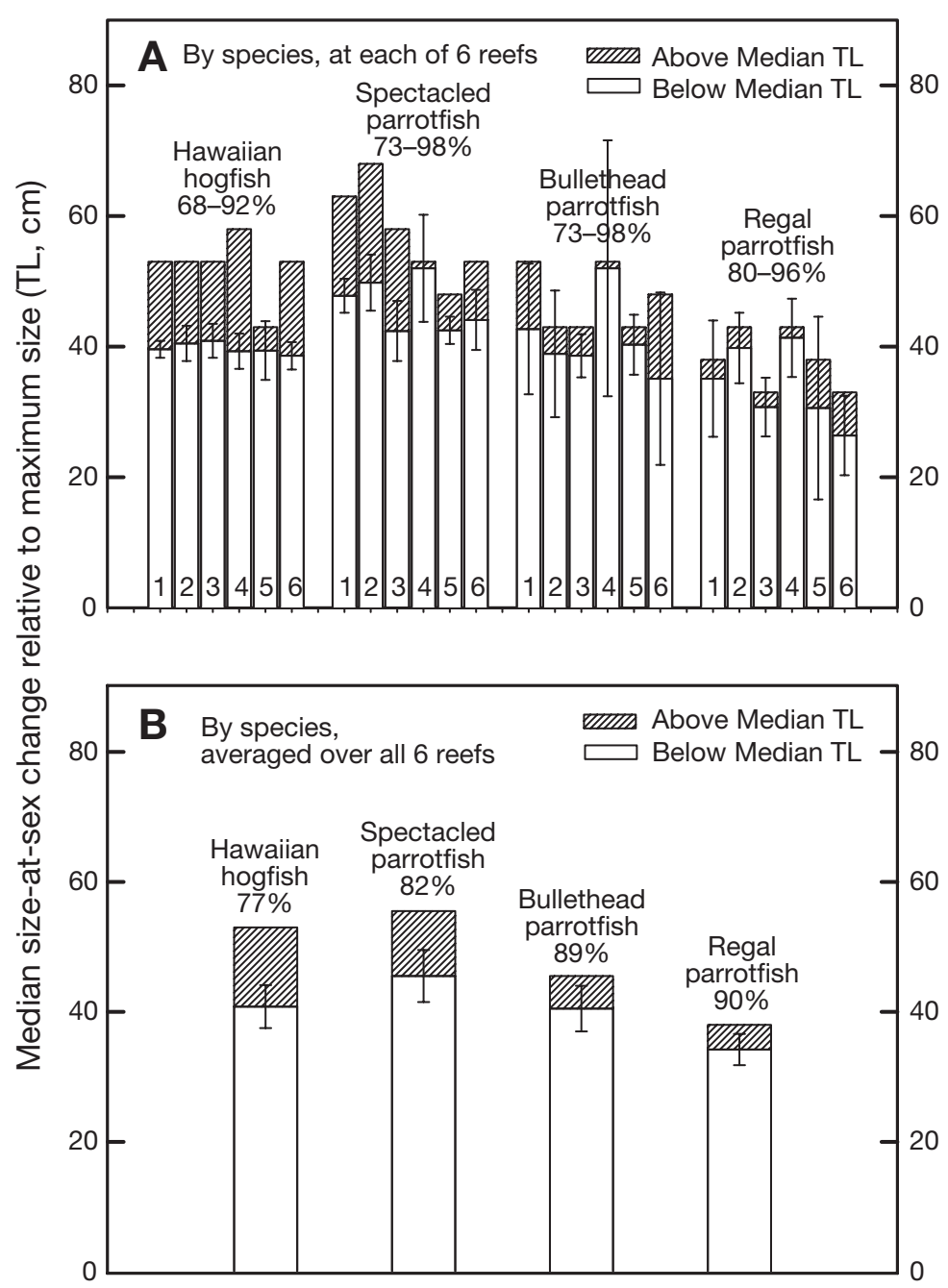

Fig. 8. Histograms of estimated median size at sex change and observed maximum size (99th percentile of observations) for each of 4 major species of labroids by species at each of the reefs and averaged over all 6 reefs surveyed during September to October 2000 and 2002. Relative size at sex change is noted as percentage of maximum size for each species and reef in (A) and for each species averaged over reefs in (B). Median sizes and SEMs (indicated by vertical bars) in (A) were estimated by logistic equation (see 'Materials and methods'); these estimates were used to generate means (and their SEMs) in (B). To improve the presentation in (A), reefs are ordered (left to right) as in Fig. 7 (where $1=$ MID, $2=\mathrm{KUR}, 3=$ MAR, $4=$ FFS, $5=$ LIS and $6=$ PHR)

piscivores as well as herbivores) were smaller at PHR argues that some environmental factor other than food availability is involved. Lastly, the consistency of the relations among labroid size at sex change, the body size distributions of labroids and other prey fishes, and giant trevally abundance-at the 3 lower-latitude drowned atolls as well as the 3 true atolls of primary focus - further indicates that the effects of predation overwhelm possibly confounding differences in latitude (water temperature), habitat structure, and degree of isolation among reefs.

\section{Density vs. body size at sex change and size distributions}

Neither the median body size of the prey reef fish assemblage nor the body size at sex change and median size of any of the 4 labroid species that dominated the biomass of this prey fish assemblage was related to density of the respective reef population in a manner suggesting intraspecific density dependence. Other prey fishes were larger, and they as well as both IP and TP spectacled parrotfish were denser at MID. Both bullethead and regal parrotfishes were denser at PHR, but the scarcity of TP fish of both species there suggests that densities did not influence (or were not importantly influenced by) social dominance interactions. Higher levels of recruitment were not operative at PHR, where recruit indices tended to be lower than at the other 2 atolls during 2000 and 2002 (DeMartini \& Friedlander 2004). Altogether, these observations suggest that the observed differences among atolls in median size and size at sex change are not simply the result of density-related sexual competition or some chance biological quirk shared by few selected species. Rather, the generality of the observations suggests that some broad-scale environmental agent is involved. We believe that this factor is generalized predation intensity that differs among atolls. If so, our observations of disproportionately abundant small-bodied prey at PHR (Figs. $2 \& 3$ ) reinforce those of Dulvy et al. (2004a,b), who suggest the existence of indirect, compensatory responses of reef fish prey to cropping by predators.

\section{Apex predation as structuring agent}

A preliminary characterization (Friedlander \& DeMartini 2002) of variations in apex predator biomass among all (excluding MID, for which data were not then available) of the 10 shallow NWHI reefs indicated manifold greater biomass densities of apex predators pooled at PHR vs. KUR. Other data besides those presented herein attest to differences in carangid densities between reefs in the NWHI: giant and bluefin (Caranx melampygus) trevallies were each less abundant at MID than FFS, based on an independent series of surveys conducted at FFS and MID between 1992 and 2000, and the magnitude of the differences between these 2 atolls increased during the 
latter half of the 1990s. Beginning in 1996 and extending through 2000, adults of the larger carangids at MID were subject to physiological stress (and possible mortality) by a recreational catch-and-release fishery, and displayed conditioned aversion to small boats and divers resulting from coincident recreational dive operations (DeMartini et al. 2002). Carangids and sharks had been fished by military personnel at KUR for over 3 decades until 1992, when the US coast guard abandoned its Long Range Navigation System (LORAN) station there (Woodward 1972). No such sustained removal of apex predators has ever occurred at PHR, as reflected by the right-skewed body size distributions of adults there. Adult populations of Caranx spp. had not rebounded at either MID or KUR, as of surveys conducted in fall 2004 (E. DeMartini unpubl. data) - not surprising given the 3 to 4 yr age at sexual maturity in these species (Sudekum et al. 1991).

Both giant and bluefin trevallies have been documented as important apex predators for which parrotfishes are a major prey item in the NWHI, where these carangids are generalized piscivores whose diets include diverse taxa of resident reef fishes ranging to sizes larger than the largest labroids (Sudekum et al. 1991). Trevallies and other transient reef fish predators, as well as reef-resident predatory fishes, have been shown to exert strong control over prey fish population structure and dynamics elsewhere (Hixon \& Carr 1997, Graham et al. 2003, also see Gust 2004). Giant trevallies transit extensively within waters surrounding the island of Oahu (Wetherbee et al. 2004), but data are lacking either for or against extensive movement among the NWHI or other islands separated by many tens of kilometers.

\section{Sexual dichromatism as sex change metric}

For protogynous labroids, estimates of body size at sex change based on external characteristics of individuals have the potential to provide nondestructive, hence preferable, proxies for examinations of gonadal state that do not require the sacrifice of individuals. This is especially important for large-bodied and other long-lived species with slow growth and low replenishment rates, for which responsible stewardship logically requires conservative protection of spawning stock. We acknowledge that an ultimate test of the most likely alternative to our hypothesis of among-atoll differences in predation pressure-that the observed differences in body size distributions represent differences in growth rates among atollswould require comparisons of labroid growth rates among atolls. However, this would require the sacrifice of many tens of individuals per species and reef, based on prior experience ageing bullethead parrotfish and congeners on Australia's Great Barrier Reef (GBR) using otoliths (Choat et al. 1996), and the likely complications of sex-specific effects (Munday et al. 2004) would further increase requisite sample sizes. Although analytically rigorous, collections of this magnitude would not constitute responsible stewardship for the relatively pristine reefs of the NWHI, where the total area of reefs is small compared to the GBR.

\section{Prey size as proxy for change in predator abundance}

Diver observations of the patchily distributed and highly mobile, often schooling, transient predators of coral reef fishes are notoriously imprecise (Connell \& Kingsford 1988), as the magnitude of variances and low power of our SPC and TDS data amply demonstrate. As apex predators provide key ecosystem functions, their influences on reef ecosystem structure and function must be quantified nonetheless, regardless of whether the abundances of predators and their prey are positively or inversely related (Stewart \& Jones 2001). The relationships we observed between giant trevally abundance and the size distribution of labroids and other prey suggest that prey size structure data, standardized as necessary for the complicating influences of habitat complexity (prey refuge size and number), variable prey recruitment, and localized productivity (Graham et al. 2005) have the potential to provide an acceptable index of predation pressure (predator abundance). Additional complications that must be resolved include the major effect of including (or excluding, as we have done) birds, mammals and fish apex predators when calculating size spectra (Jennings \& Mackinson 2003). Because of likely difficulties in controlling for spatial influences on size spectra, we expect that size spectra might be more suitable for detecting temporal changes at a reef, rather than differences among reefs, assuming that fishing or other temporal impacts do not degrade habitat. The precision attainable when comparing size frequency distributions of numerous small prey is usually much better than that possible when comparing density estimates of mobile schooling or otherwise patchily distributed predatory fishes on reefs (Thresher \& Gunn 1986). Tag-recapture estimates of predator abundance are extremely costly and often unsuccessful. Fishing-down experiments in theory can provide more precise and perhaps more accurate estimates of the abundances of apex predators and other large, sparsely distributed fishes, but such are unlikely in the NWHI given the present management philosophy. 
Any modern and reasonable definition of 'predation' for reef fishes must include exploitation by humans as well as natural attrition. Examples of the effects of human extraction on the size and age distributions of reef fish stocks are now commonplace (reviewed by Jennings \& Lock 1996); other investigators have reported exploitation effects on the sex ratios or maturity schedules of labrids (Cowen 1990, Platten et al. 2002), scarids (Hawkins \& Roberts 2003), and aggregation-spawning epinepheline groupers (Coleman et al. 1996, Beets \& Friedlander 1999). Because of the influence of fishing, particularly the selective harvest of apex predators and large terminal phase males, it is usually difficult to examine the effects of natural predation on prey body size distributions or on sizes at sex change in most coral reef ecosystems. The reefs of the NWHI are among the few remaining large-scale, intact, predator-dominated reef ecosystems left in the world, and offer a unique opportunity to understand how unaltered ecosystems are structured and how they function in the absence of human intervention (Friedlander \& DeMartini 2002). Data generated by studies that are possible only at places like the NWHI are essential for interpreting patterns observed in most other reef systems where natural predation and human extraction are concurrent and confound one another (see Jennings \& Mackinson 2003).

Relatively available indices of life-history traits (such as maximum body size as a proxy for replenishment rate and relative body size distribution as a proxy for mortality rate) have been identified as surrogate reference points for managing fishery stocks within coral reef ecosystems (Denny et al. 2002, Dulvy et al. 2004b, Graham et al. 2005). We recommend that size spectra and the body size distributions of prey be evaluated as possible complementary means for comparing predator estimates when evaluating temporal changes in predation pressure that either occur naturally or that might result from trophic cascades due to human exploitation of apex predators.

Acknowledgements. Funding support from NOAA's Coral Reef Conservation Program through the NOAA Fisheries Office of Habitat Conservation and the NOAA NWHI Coral Reef Ecosystem Reserve is greatly appreciated. We thank the officers and crew of the NOAA ship 'Townsend Cromwell' and the RV 'Rapture' and our many colleagues in the Coral Reef Ecosystem Division of the Pacific Islands Fisheries Science Center for helping to plan and execute the cruises, and especially the many diver-observers (particularly R. Kosaki, W. Walsh, S. Cotton, and B. Zgliczynski) for assistance in conducting fish surveys. We also thank J. D. Parrish (Hawaii Cooperative Fishery Research Unit, US Geological Survey, University of Hawaii at Manoa) for sharing unpublished data on the size distribution of prey consumed by carangids in the NWHI, and J. Beets, N. Graham, P. Munday and 3 anonymous reviewers for critiquing drafts of the manuscript.

\section{LITERATURE CITED}

Allsop DJ, West SA (2003a) Constant relative age and size at sex change for sequentially hermaphroditic fish. J Evol Biol 6:921-929

Allsop DJ, West SA (2003b) Changing sex at the same relative body size. Nature 425:783-784

Alonzo SH, Mangel M (2004) The effects of size-selective fisheries on the stock dynamics of and sperm limitation in sex-changing fish. Fish Bull (U.S.) 102:1-13

Armsworth PR (2001) Effects of fishing on a protogynous hermaphrodite. Can J Fish Aquat Sci 58:568-578

Barot S, Heino M, O'Brien L, Dieckmann U (2004) Long-term trend in the maturation reaction norm of two cod stocks. Ecol Appl 14:1257-1271

Beets J, Friedlander A (1999) Evaluation of a conservation strategy: a spawning aggregation closure for red hind, Epinephelus guttatus, in the US Virgin Islands. Environ Biol Fish 55:91-98

Bohnsack JA, Bannerot SP (1986) A stationary visual census technique for quantitatively assessing community structure of coral reef fishes. NOAA Tech Rep NMFS 41:1-15

Bortone SA, Kimmel J (1991) Environmental assessment and monitoring of artificial habitats. In: Seaman W Jr, Sprague LM (eds) Artificial habitats for marine and freshwater fisheries. Academic Press, San Diego, CA, p 177-236

Bruce RL (1980) On the occurrence of very small terminal phase parrotfishes. Copeia 1980(4):887-889

Charnov EL (1993) Life history invariants. Oxford University Press, Oxford

Charnov EL, Skulladottir U (2000) Dimensionless invariants for the optimal size (age) of sex change. Evol Ecol Res 2: $1067-1071$

Choat JH, Robertson DR (1975) Protogynous hermaphroditism in fishes of the family Scaridae. In: Reinboth R (ed) Intersexuality in the animal kingdom. Springer-Verlag, Berlin, p 263-283

Choat JH, Axe LM, Lou DC (1996) Growth and longevity in fishes of the family Scaridae. Mar Ecol Prog Ser 145:33-41

Coleman FC, Koenig CC, Collins IA (1996) Reproductive styles of shallow-water groupers (Pisces: Serranidae) in the eastern Gulf of Mexico and the consequences of fishing spawning aggregations. Environ Biol Fish 47:129-141

Connell SD, Kingsford MJ (1988) Spatial, temporal, and habitat-related variation in the abundance of large predatory fish at One Tree Reef, Australia. Coral Reefs 17:49-57

Cowen RK (1990) Sex change and life history patterns of the labrid, Semicossyphus pulcher across an environmental gradient. Copeia 1990:787-795

DeMartini EE (2004) Habitat and endemism of recruits to shallow reef fish populations: selection criteria for no-take MPAs in the NWHI Coral Reef Ecosystem Reserve. Bull Mar Sci 74:185-205

DeMartini EE, Friedlander AM (2004) Spatial patterns of endemism in shallow-water reef fishes of the Northwestern Hawaiian Islands. Mar Ecol Prog Ser 271:281-296

DeMartini EE, Sikkel P (in press) Reproductive ecology of California marine fishes. In: Allen LG, Horn MH, Pondella DJ (eds) Ecology of California marine fishes. University of California Press, Berkeley, CA

DeMartini EE, Parrish FA, Boland RC (2002) Comprehensive evaluation of shallow reef fish populations at French Frigate Shoals and Midway Atoll, Northwestern Hawaiian Islands (1992/93, 1995-2000). NOAA Technical Memorandum NOAA Tech Memo NMFS SWFSC-347:1-54

Denny NH, Jennings S, Reynolds JD (2002) Life-history correlates of maximum population growth rates in marine 
fishes. Proc R Soc Lond B 269:2229-2237

Dulvy NK, Freckleton RP, Polunin NVC (2004a) Coral reef cascades and indirect effects of predator removal by exploitation. Ecol Lett 7:410-416

Dulvy NK, Polunin NVC, Mill AC, Graham NAJ (2004b) Sizestructural change in lightly exploited coral reef fish communities: evidence for weak indirect effects. Can J Fish Aquat Sci 61:466-475

Friedlander AM, DeMartini EE (2002) Contrasts in density, size, and biomass of reef fishes between the northwestern and the main Hawaiian Islands: the effects of fishing down apex predators. Mar Ecol Prog Ser 230:253-264

Geertjes GJ, Postema J, Kamping A, van Delden W, Videler JJ, van de Zande L (2004) Allozymes and RAPDs detect little genetic population substructuring in the Caribbean stoplight parrotfish Sparisoma viride. Mar Ecol Prog Ser 279:225-235

Graham NAJ, Evans RD, Russ GR (2003) The effects of marine reserve protection on the trophic relationships of reef fishes on the Great Barrier Reef. Environ Conserv 30: 200-208

Graham NAJ, Dulvy NK, Jennings S, Polunin NVC (2005) Size spectra as indicators of the effects of fishing on coral reef fish assemblages. Coral Reefs 24:118-124

Gust N (2004) Variation in the population biology of protogynous coral reef fishes over tens of kilometres. Can J Fish Aquat Sci 61:205-218

Hawkins JP, Roberts CM (2003) Effects of fishing on sexchanging Caribbean parrotfishes. Biol Conserv 115:213-226

Hixon MA, Carr MH (1997) Synergistic predation, density dependence, and population regulation in marine fish. Science 277:946-949

Jennings S, Lock JM (1996) Population and ecosystem effects of reef fishing. In: Polunin NV, Roberts CM (eds) Reef fisheries. Chapman \& Hall, London, p 193-217

Jennings S, Mackinson S (2003) Abundance-body mass relationships in size-structured food webs. Ecol Lett 6:971-974

Manly BFJ (1991) Randomization and Monte Carlo methods in biology. Chapman \& Hall, New York

Moyer JT (1991) Comparative mating strategies in labrid fishes. Mongraph No 1, Watanabe Ichthyological Institute, Tokyo

Munday PL, Hodges AL, Choat JH, Gust N (2004) Sexspecific growth effects in protogynous hermaphrodites. Can J Fish Aquat Sci 61:323-327

Olsen EM, Heino M, Lilly GR, Morgan MJ, Brattey J, Ernande B, Dieckmann U (2004) Maturation trends indicative of rapid evolution preceded the collapse of northern cod. Nature 428:932-935

Petersen CW, Warner RR (2002) The ecological context of reproductive behavior. In: Sale PF (ed) Coral reef fishes: dynamics and diversity in a complex ecosystem. Academic Press, New York, p 103-118

Editorial responsibility: Charles Birkeland (Contributing Editor), Honolulu, Hawaii, USA
Platten JR, Tibbetts IR, Sheaves MJ (2002) The influence of increased line-fishing mortality on the sex ratio and age of sex reversal of the venus tusk fish. J Fish Biol 60:301-318

Randall JE (1996) Shore fishes of Hawaii. Natural World Press, Vida, OR

Reznick DA, Bryga H, Endler JA (1990) Experimentally induced life-history evolution in a natural population. Nature 346:357-359

Rijnsdorp AD (1993) Fisheries as a large-scale experiment on life-history evolution: disentangling phenotypic and genetic effects in changes in maturation and reproduction in North Sea plaice, Pleuronectes platessa. Oecologia 96: 391-401

Robertson DR, Warner RR (1978) Sexual patterns in labroid fishes of the western Caribbean, II: the parrotfishes (Scaridae). Smithson Contrib Zool 255:1-26

Robertson DR, Reinboth R, Bruce RW (1982) Gonochorism, protogynous sex change and spawning in three sparisomatinine parrotfishes from the western Indian Ocean. Bull Mar Sci 32:868-879

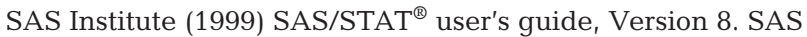
Institute, Cary, NC

Siegel S, Castellan JJ Jr (1988) Nonparametric statistics for the behavioral sciences, 2nd edn. McGraw-Hill, New York

Sokal RR, Rohlf FJ (1981) Biometry. The principles and practice of statistics in biological research, 2nd edn. WH Freeman, New York

Stewart BD, Jones GP (2001) Associations between the abundance of piscivorous fishes and their prey on coral reefs: implications for prey-fish mortality. Mar Biol 138:383-397

Sudekum AE, Parrish JD, Radtke RL, Ralston S (1991) Life history and ecology of large jacks in undisturbed, shallow oceanic communities. Fish Bull (U.S.) 89:493-513

Thresher RE, Gunn JS (1986) Comparative analysis of visual census techniques for highly mobile, reef-associated piscivores (Carangidae). Environ Biol Fish 17:93-116

Warner RR (1975) The adaptive significance of sequential hermaphroditism in animals. Am Nat 109:61-82

Warner RR (1988) Sex change and the size-advantage model. Trends Ecol Evol 3:133-136

Warner RR, Robertson DR (1978) Sexual patterns in labroid fishes of the western Caribbean, I: the wrasses (Labridae). Smithson Contrib Zool 254:1-27

Warner RR, Robertson DR, Leigh EG Jr (1975) Sex change and sexual selection. Science 190:633-638

Wetherbee BM, Holland KN, Meyer CG, Lowe CG (2004) Use of a marine reserve in Kaneohe Bay, Hawaii by the giant trevally, Caranx ignobilis. Fish Res 67:253-263

Woodward PW (1972) The natural history of Kure Atoll, Northwestern Hawaiian Islands. Atoll Res Bull 164:1-318

Zar JH (1984) Biostatistical analysis, 2nd edn. Prentice-Hall, Englewood Cliffs, NJ

Submitted: June 21, 2004; Accepted: January 26, 2005

Proofs received from author(s): July 11, 2005 